\title{
Spatial variability in persistent organic pollutants and polycyclic aromatic hydrocarbons found in beach-stranded pellets along the coast of the state of São Paulo, southeastern Brazil
}

\author{
Satie Taniguchi a,*, Fernanda I. Colabuono a ${ }^{a}$ Patrick S. Dias ${ }^{a}$, Renato Oliveira a , Mara Fisner ${ }^{\text {a }}$, Alexander Turra ${ }^{\text {a }}$, \\ Gabriel M. Izar ${ }^{\text {c }}$, Denis M.S. Abessa ${ }^{\text {c }}$, Mahua Saha ${ }^{\text {b }}$, Junki Hosoda ${ }^{\text {b }}$, Rei Yamashita ${ }^{\mathrm{b}}$, Hideshige Takada ${ }^{\mathrm{b}}$, \\ Rafael A. Lourenço ${ }^{a}$, Caio A. Magalhães ${ }^{a}$, Márcia C. Bícego a , Rosalinda C. Montone ${ }^{\text {a }}$ \\ a Universidade de São Paulo, Instituto Oceanográfico, Praça do Oceanográfico, 191, 05508-120 São Paulo, SP, Brazil \\ ${ }^{\mathrm{b}}$ Laboratory of Organic Geochemistry, Tokyo University of Agriculture and Technology, Tokyo, Japan \\ ${ }^{c}$ Universidade Estadual Paulista (UNESP), Praça Infante D. Henrique s/nº 11330-900 São Vicente, SP, Brazil
}

\section{A R T I C L E I N F O}

Article history:

Received 12 February 2016

Received in revised form 10 March 2016

Accepted 14 March 2016

Available online 25 March 2016

\section{Keywords:}

Pellets

Brazil

São Paulo

Polychlorinated biphenyls

Polycyclic aromatic hydrocarbons

Organochlorine pesticides

\begin{abstract}
A B S T R A C T
High spatial variability in polycyclic aromatic hydrocarbons (PAHs), polychlorinated biphenyls (PCBs), organochlorine pesticides, such as DDTs, and polybrominated diphenylethers was observed in plastic pellets collected randomly from 41 beaches ( 15 cities) in 2010 from the coast of state of São Paulo, southeastern Brazil. The highest concentrations ranged, in $\mathrm{ng} \mathrm{g}^{-1}$, from 192 to $13,708,3.41$ to 7554 and $<0.11$ to 840 for PAHs, PCBs and DDTs, respectively. Similar distribution pattern was presented, with lower concentrations on the relatively less urbanized and industrialized southern coast, and the highest values in the central portion of the coastline, which is affected by both waste disposal and large port and industrial complex. Additional samples were collected in this central area and PCB concentrations, in $\mathrm{ng} \mathrm{g}^{-1}$, were much higher in 2012 (1569 to 10,504) than in 2009/ 2010 (173 to 309) and 2014 (411), which is likely related to leakages of the PCB commercial mixture.
\end{abstract}

(C) 2016 Elsevier Ltd. All rights reserved.

\section{Introduction}

The shoreline of the state of São Paulo is located on the southeastern coast of Brazil, extends for $860 \mathrm{~km}$ and includes one of the most economically important metropolitan areas in South America. Sixteen cities make up the São Paulo shoreline, with a total of 2.166 million habitants (Brasil, 2015) and the same problems as all large coastal metropolises, such as atmospheric pollution (Lamparelli et al., 2001), overpopulation during holidays and the summer season, and large quantities of inadequately managed waste (Gutberlet, 1997), such as the Santos sewage outfall, which is a significant source of contamination in Santos Bay (Abessa et al., 2005). Moreover, the existence of a major industrial center (Cubatão Industrial Complex), the largest port (Port of Santos) and the largest oil terminal (Almirante Barroso Maritime Terminal) in Latin America also contribute significantly to the input of organic contaminants in the marine environment. As a result of anthropogenic activities in this area, many pollutants, such as polycyclic aromatic hydrocarbons (PAHs), polychlorinated biphenyls (PCBs) and organochlorine pesticides (OCPs),

\footnotetext{
* Corresponding author.

E-mail address: satie@usp.br (S. Taniguchi).
}

have been found in the environment (e.g., Lamparelli et al., 2001; Bícego et al., 2006).

Pollution by PAHs has been the focus of attention due to the widespread occurrence and high degrees of toxicity. The main source of PAHs is anthropogenic, including the burning of fossil fuels or biomass and the release of hydrocarbons related to the petroleum industry (Baumard et al., 1999). PCBs, OCPs and polybrominated diphenylethers (PBDEs) are ubiquitous environmental contaminants that are recognized as persistent organic pollutants (POPs) (Jones and de Voogt, 1999). Once in seawater, these contaminants are adsorbed at concentrations of up to $10^{6}$ to the surface of small plastic pellets that are released unintentionally into the environment during manufacturing and transport, reaching a large number of beaches around the world (Mato et al., 2001). Plastic pellets are easily collectable and have been used as a lowcost monitoring medium to assess organic pollutants in the marine environment (Ogata et al., 2009; Karapanagioti et al., 2011; Hirai et al., 2011; Heskett et al., 2012; Fisner et al., 2013a,b).

Organic pollutants associated with plastic pellets exhibit a high degree of variability among countries, with higher concentrations in areas subjected to considerable industrial (PCBs and DDTs) or agricultural (HCHs) activities (International Pellet Watch, http://www. pelletwatch.org/maps/). The open sea and remote beaches have lower 
concentrations of organic pollutants (Hirai et al., 2011). Although the global and local components of spatial variability in the occurrence of organic pollutants in plastic pellets have been addressed, regional patterns still require clarification.

In the present study, PAHs, PCBs, OCPs and PBDEs were evaluated in plastic pellets sampled from 41 beaches ( 15 cities) along the coastline of the state of São Paulo (southeastern Brazil) and spatial variability was investigated. Moreover, samples from the central portion of the coastline, which is the most affected area, were collected during 2009/ 2010, 2012 and 2014 for the determination of temporal trends in PCB levels.

\section{Material and methods}

Plastic pellets were collected from the sand surface with tweezers and placed in aluminum envelopes identified with a label. Sampling was conducted in two different ways. Firstly, plastic pellets of different colors were collected in 2010 from 41 beaches located in 15 cities along the coast of the state of São Paulo (Fig. 1), which has an extension of $860 \mathrm{~km}, 427 \mathrm{~km}$ of which are formed by beaches (http://www. cidadespaulistas.com.br). The pellets were chosen randomly to obtain results that represent the overall pollution of each area. Secondly, time-series samples were collected from the central coast of the state near the Port of Santos and Cubatão Industrial Complex in 2009/2010, 2012 and 2014. During these sampling events, only yellowing pellets were collected to reduce individual differences in POP concentrations and allow a better comparison with other areas of the world. Yellowing pellets tend to have higher concentrations of POPs, since they have been in seawater for a longer time and consequently have accumulated more contaminants (Endo et al., 2005; Ogata et al., 2009). The central area is known as Baixada Santista and includes the cities of Peruíbe, Itanhém, Mongaguá, Praia Grande, São Vicente, Cubatão, Santos, Guarujá and Bertioga, which together have a population of approximately 1.8 million people, out of the 2.04 million (Brasil, 2015) who live along the entire shoreline of the state of São Paulo.

Pellet samples from the 41 beaches were analyzed at the oceanographic institute laboratory of the University of São Paulo. The analysis was carried out in pools containing approximately $1 \mathrm{~g}$ of pellets. Each sample was soxhlet-extracted with dichloromethane/n-hexane. The extract was cleaned up through adsorption chromatography using a column of alumina deactivated with $5 \%$ water. PAHs, PCBs and PBDEs were identified and quantified using gas chromatography and mass spectrometry (GC/MS). Organochlorine pesticides were analyzed using a gas chromatograph with an electron capture detector (GCECD), as described in Colabuono et al. (2010).

The chlorinated pesticides analyzed were DDTs ( $o, p^{\prime}$-DDT, $p, p^{\prime}$-DDT, $o, p^{\prime}$-DDD, $p, p^{\prime}$-DDD, $o, p^{\prime}$-DDE and $p, p^{\prime}$-DDE), chlordanes $(\alpha-$ and $\gamma$ chlordane, oxychlordane, heptachlor and heptachlor epoxide), HCHs $(\alpha-, \beta-, \gamma-$ and $\delta-H C H)$, Drins (aldrin, dieldrin, isodrin and endrin), HCB and Mirex. The PCBs investigated were the sum of 51 congeners (IUPAC \#8, 18, 28, 31, 33, 44, 49, 52, 56/60, 66, 70, 74, 77, 81, 87, 95, $97,99,101,105,110,114,118,123,126,128,132,138,141,149,151$, $153,156,157,158,167,169,170,174,177,180,183,187,189,194$, 195, 201, 203, 206, 209). The PBDEs analyzed were IUPAC \#28, 47, 99, $100,153,154$ and 183 . The sixteen US EPA priority PAHs (naphthalene, acenaphthylene, acenaphthene, phenanthrene, anthracene, fluorene, fluoranthene, benzo[a]anthracene, chrysene, benzo[b]fluoranthene, benzo[k]fluoranthene, pyrene, benzo[a]pyrene, indeno[1,2,3cd]pyrene, dibenz[ah]anthracene, benzo[ghi]perylene) and their alkyl substituted compounds were also analyzed.

Quality assurance and quality control were carried out based on Wade and Cantillo (1994) through an analysis of the sample parameters, procedural blanks, matrix spikes, precision tests with matrix replicates and standard reference material (SRM1944 - organic pollutants in sediment from New Jersey) from the US National Institute of Standards and Technology. Both instruments from Agilent Technologies were calibrated with the injection of nine different concentrations of certified standards. The individual identification of OCPs, PCBs, PAHs and PBDEs was based on GC retention times. For PAHs, PCBs and PBDEs, the respective mass to charge ratio $(\mathrm{m} / \mathrm{z})$ was also used. The method detection limit (MDL) was based on the standard deviation (Student's t value with 95\% confidence) of seven replicates of a spiked sample containing target compounds at a low concentration. The MDL ranged from 1.00 to $3.70 \mathrm{ng} \mathrm{g}^{-1}$ for PAHs, 0.51 to $2.12 \mathrm{ng} \mathrm{g}^{-1}$ for PCBs, 0.08 to $1.86 \mathrm{ng} \mathrm{g}^{-1}$ for OCPs and 0.76 to $1.06 \mathrm{ng} \mathrm{g}^{-1}$ for PBDEs. All solvents were organic residue analysis grade (J.T. Baker) and the blanks were checked under the same conditions as those of the analyses. Concentrations of analytes were expressed as $n \mathrm{~g} \mathrm{~g}^{-1}$ dry weight.

The time-series samples were analyzed in the laboratory of organic geochemistry of the Tokyo University of Agriculture and Technology (Tokyo, Japan). Yellowing pellets $(30<$ yellowness $<50$ ) were extracted by soaking with hexane. The extracts were separated using fully activated silica gel column chromatography into three fractions: Fraction I - n-

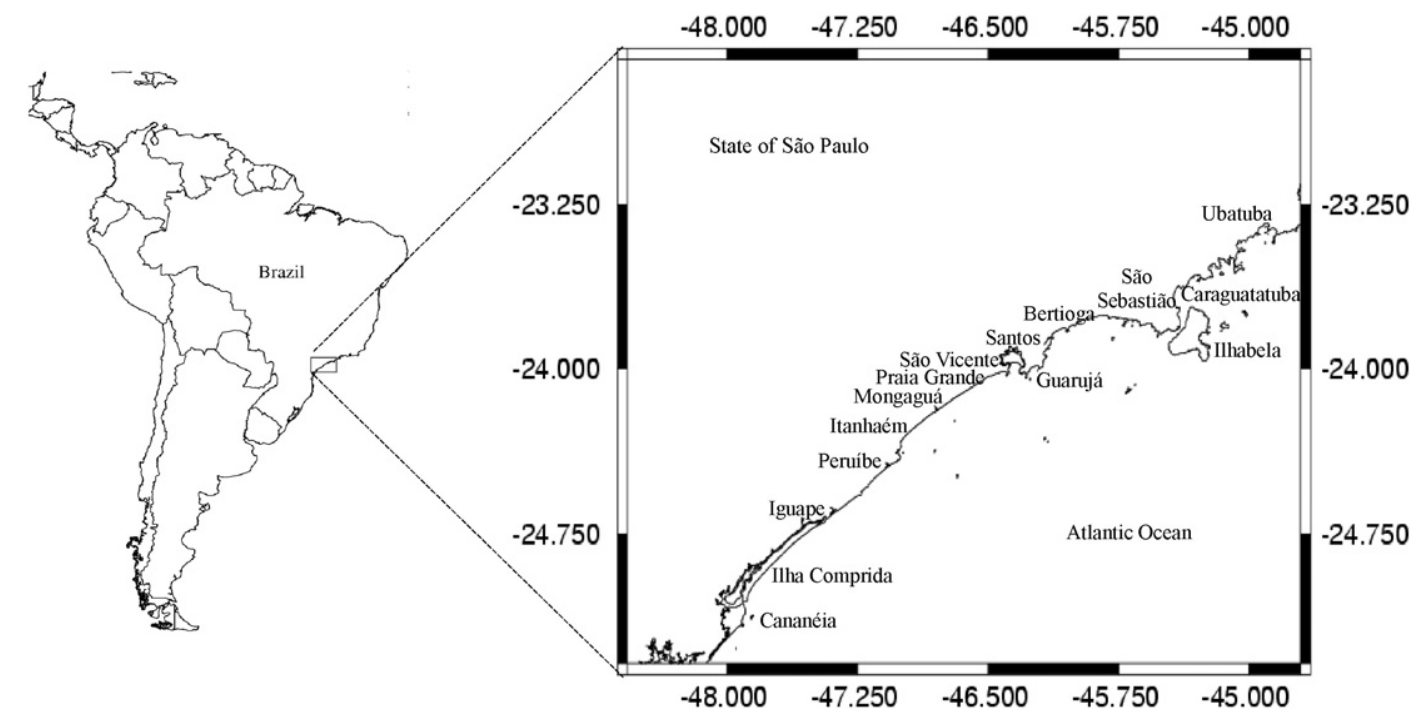

Fig. 1. Coastline of state of São Paulo and location of cities from which plastic pellets were collected. 
alkanes and hopanes; Fraction II - PCB and LABs (linear alkylbenzenes); and Fraction III - PAHs. In Fraction II, 13 PCB congeners ranging from tetrachlorobiphenyl (CB66) to decachlorobiphenyl (CB209) were determined using gas chromatography/ion-trap mass spectrometry [details are available in Ogata et al. (2009) and Hirai et al. (2011)]. The compatibility of analytical values between the laboratories of the University of São Paulo and Tokyo University of Agriculture and Technology was confirmed as follows: hexane-extracted pellets were re-extracted with DCM/hexane using a Soxhlet apparatus and no significant PCBs were detected; organic extracts from environmental pellets were analyzed in both laboratories and the analytical values were in agreement within 1\%. For International Pellet Watch (IPW), the Tokyo organic geochemistry laboratory normally analyzes five pools (each pool consisting of five pellets) for each location and takes the median value as representative for the analytical results of individual locations. In the present study, however, the arithmetic mean of five pools was calculated to be consistent with the values determined by the laboratory of the University of São Paulo.

\section{Results and discussion}

Table 1 displays the concentrations of PAHs and POPs (PCBs, OCPs and PBDEs) evaluated in the present study. The overall concentrations [ng $\mathrm{g}^{-1}$ (in parentheses: mean for each city)] found in pellets from the 15 cities along the coast of the state of São Paulo ranged from 192 to 13,708 (465 to 8540 ) for PAHs, 3.41 to 7554 (78.0 to 1295) for PCBs, $<0.11$ to 840 ( 7.88 to 447 ) for DDTs, $<0.46$ to 58.7 (1.4 to 44.4 ) for $\mathrm{HCB},<0.74$ to 105 (1.8 to 55.8) for Mirex, $<0.24$ to $4.10(<0.24$ to 3.1) for $\mathrm{HCH},<0.08$ to 64.0 (1.06 to 39.0) for chlordanes, $<0.44$ to 37.8

Table 1

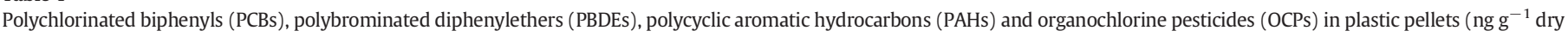
weight) collected along the coast of the state of São Paulo, Brazil [location column lists municipalities (bold) and beaches sampled; mean concentration in bold type].

\begin{tabular}{|c|c|c|c|c|c|c|c|c|c|c|}
\hline Location & $\Sigma_{51} \mathrm{PCBs}$ & $\Sigma_{13} \mathrm{PCBs}$ & ¿PBDEs & ¿PAHs & $\Sigma_{16} \mathrm{PAHs}$ & ¿DDTs & $\mathrm{HCB}$ & Mirex & $\sum \mathrm{HCHs}$ & $\sum$ Chlordanes \\
\hline Cananéia & 77.7 & 15.6 & 0.88 & 465 & 40.2 & 10.3 & 1.12 & $<\mathbf{1 . 7 4}$ & 1.34 & 5.97 \\
\hline Enseada da Baleia & 3.41 & $<0.51$ & $<0.76$ & 802 & 49.1 & 7.61 & 0.79 & $<1.74$ & 2.16 & 0.49 \\
\hline Marujá & 39.5 & 23.3 & 2.63 & 398 & 36.5 & 18.5 & $<0.46$ & $<1.74$ & 0.48 & 5.90 \\
\hline Itacuruçá & 190 & 23.4 & $<0.76$ & 194 & 34.9 & 4.89 & 1.46 & $<1.74$ & 1.37 & 11.5 \\
\hline Ilha Comprida & 269 & 201 & $<0.76$ & 1229 & 193 & 8.9 & 12.5 & 13.3 & 2.22 & 9.87 \\
\hline Boqueirão Sul & 14.1 & 7.70 & $<0.76$ & 336 & 47.4 & 7.88 & 0.89 & $<1.74$ & 3.43 & 1.29 \\
\hline Viareggio & 742 & 559 & $<0.76$ & 220 & 41.5 & 12.2 & $<0.46$ & $<1.74$ & $<0.24$ & 1.74 \\
\hline Boqueirão Norte & 51.6 & 36.4 & $<0.76$ & 3132 & 491 & 6.66 & 24.1 & 13.3 & 2.91 & 26.6 \\
\hline Iguape & 126 & 27.5 & $<0.76$ & 192 & 33.8 & 11.4 & 1.38 & 1.79 & 1.24 & $<0.08$ \\
\hline Juréia & 126 & 27.5 & $<0.76$ & 192 & 33.8 & 11.4 & 1.38 & 1.80 & 1.24 & $<0.08$ \\
\hline Peruíbe & 109 & 77.9 & $<0.76$ & 608 & 127 & 31.4 & 3.11 & 12.5 & 1.10 & 1.29 \\
\hline Guaraú & 163 & 117 & $<0.76$ & 466 & 80 & 24.8 & 6.83 & 4.0 & 1.88 & 3.04 \\
\hline Peruíbe Centro & 80.8 & 61.4 & $<0.76$ & 844 & 268 & 14.5 & 1.70 & 29.9 & 1.10 & 0.82 \\
\hline Ruínas do Abarebebê & 81.8 & 55.0 & $<0.76$ & 514 & 32.6 & 54.7 & 0.79 & 3.50 & 4.70 & $<0.08$ \\
\hline Itanhaém & 249 & 161 & $<0.76$ & 397 & 84.6 & 30.3 & 2.01 & 6.49 & 0.66 & 14.0 \\
\hline Balneário Gaivota & 480 & 336 & $<0.76$ & 308 & 46.9 & 57.4 & 1.20 & 15.2 & 0.66 & 6.62 \\
\hline Praia do Sonho & 121 & 88.0 & $<0.76$ & 372 & 90.4 & 15.2 & 1.09 & 1.80 & 2.07 & 33.6 \\
\hline Jardim Suarão & 147 & 58.7 & $<0.76$ & 512 & 116 & 18.4 & 3.74 & 2.50 & $<0.24$ & 1.70 \\
\hline Mongaguá & 240 & 177 & 0.46 & 421 & 73.7 & 84.9 & 5.58 & 21.7 & 0.59 & 9.94 \\
\hline Vera Cruz & 234 & 173 & $<0.76$ & 733 & 129 & 175 & 6.37 & 5.00 & 1.17 & 26.4 \\
\hline Vila São Paulo & 487 & 357 & 0.91 & 529 & 91.6 & 79.8 & 10.4 & 60.1 & $<0.24$ & 3.44 \\
\hline Praia Grande & 357 & 247 & 0.82 & 1593 & 534 & 87.4 & 8.96 & 9.41 & 1.67 & 3.57 \\
\hline Balneário Real & 71.4 & 59.2 & $<0.76$ & 401 & 159 & 26.6 & 3.08 & 2.10 & 0.86 & 0.95 \\
\hline Vila Mirim & 546 & 377 & 1.12 & 1235 & 449 & 151 & 15.0 & 20.3 & 2.18 & 5.34 \\
\hline Guilhermina & 453 & 304 & 1.33 & 3144 & 995 & 84.5 & 8.82 & 5.90 & 5.47 & 4.43 \\
\hline São Vicente & 111 & 100 & $<0.76$ & 797 & 512 & 40.3 & 4.75 & 9.09 & 2.47 & 1.06 \\
\hline Itararé & 111 & 100 & $<0.76$ & 797 & 512 & 40.3 & 4.75 & 9.1 & 2.47 & 1.06 \\
\hline Santos & 818 & 551 & 2.0 & 8540 & 1256 & 441 & 44.4 & 55.8 & 1.48 & 22.9 \\
\hline Gonzaga & 524 & 371 & 2.67 & 3373 & 654 & 41.8 & 30.1 & 6.70 & 1.97 & 3.32 \\
\hline Ponta da Praia & 1112 & 730 & 1.23 & 13,708 & 1857 & 840 & 58.7 & 105 & 1.78 & 42.5 \\
\hline Guarujá & 1295 & 845 & 0.54 & 1425 & 277 & 237 & 8.59 & 5.46 & 1.64 & 6.49 \\
\hline Pitangueiras & 3030 & 2062 & 1.61 & 869 & 209 & 618 & 17.1 & 10.2 & 9.45 & 15.6 \\
\hline Tijucopava & 276 & 177 & $<0.76$ & 701 & 349 & 52.7 & 2.80 & 3.60 & 2.99 & 1.22 \\
\hline Mar Casado & 452 & 296 & $<0.76$ & 2706 & 273 & 41.5 & 5.80 & 2.60 & 2.32 & 2.67 \\
\hline Bertioga & 388 & 276 & 0.34 & 1783 & 774 & 63.9 & 5.15 & 4.96 & 3.14 & 8.92 \\
\hline Enseada & 336 & 235 & $<0.76$ & 4518 & 2068 & 61.8 & 7.6 & 3.8 & 3.67 & 2.23 \\
\hline Riviera de São Lourenço & 451 & 309 & $<0.76$ & 549 & 165 & $<0.11$ & 4.1 & $<1.74$ & 2.53 & 15.4 \\
\hline Boracéia & 378 & 283 & 1.03 & 282 & 88.1 & 130 & 3.80 & 6.10 & 4.10 & 9.12 \\
\hline São Sebastião & 481 & 308 & 0.47 & 2997 & 655 & 235 & 26.1 & 7.17 & 1.68 & 21.3 \\
\hline Juquehy & 644 & 434 & 0.88 & 2888 & 575 & 351 & 8.50 & 11.5 & 2.42 & 7.06 \\
\hline Maresias & 593 & 388 & $<0.76$ & 4023 & 1350 & 315 & 37.9 & $<1.74$ & 1.14 & 2.30 \\
\hline Barequeçaba & 130 & 62.5 & $<0.76$ & 2731 & 269 & 0.00 & 25.0 & $<1.74$ & 0.62 & 11.7 \\
\hline Arrastão & 556 & 348 & 0.98 & 2346 & 426 & 275 & 32.9 & 2.80 & 2.54 & 64.0 \\
\hline Ilhabela & 268 & 177 & $<0.76$ & 1911 & 230 & 108 & 9.78 & 2.38 & 1.44 & 8.94 \\
\hline Castelhanos & 252 & 149 & $<0.76$ & 1118 & 120 & 16.8 & 10.5 & 2.90 & 2.11 & 6.52 \\
\hline Perequê & 116 & 75.8 & $<0.76$ & 692 & 73.4 & 29.5 & 5.90 & 1.80 & 1.54 & 0.63 \\
\hline Jabaquara & 436 & 307 & $<0.76$ & 3924 & 496 & 279 & 13.0 & $<1.74$ & 1.82 & 19.7 \\
\hline Caraguatatuba & 759 & 499 & $<0.76$ & 3958 & 861 & 288 & 14.8 & 5.53 & 2.44 & 39.0 \\
\hline Flexeiras & 1065 & 647 & $<0.76$ & 5919 & 1073 & 261 & 30.2 & 2.40 & 2.37 & 62.7 \\
\hline Camaroeiro & 359 & 262 & $<0.76$ & 626 & 86.7 & 241 & 5.40 & 9.80 & 1.93 & 4.24 \\
\hline Mocóca & 854 & 587 & $<0.76$ & 5329 & 1423 & 361 & 8.70 & 4.40 & 6.11 & 50.0 \\
\hline Ubatuba & 272 & 183 & $<0.76$ & 3327 & 577 & 44.3 & 14.5 & 15.8 & 1.86 & 5.47 \\
\hline Lázaro & 269 & 166 & $<0.76$ & 4133 & 788 & 38.9 & 24.3 & 38.2 & 1.23 & 11.1 \\
\hline Praia Grande & 341 & 226 & $<0.76$ & 3846 & 541 & 17.0 & 15.0 & 8.50 & $<0.24$ & 2.18 \\
\hline Félix & 224 & 162 & $<0.76$ & 1820 & 423 & 58.0 & 3.4 & 11.20 & 9.49 & $<0.08$ \\
\hline Fazenda & 254 & 177 & $<0.76$ & 3509 & 558 & 63.3 & 15.1 & 5.50 & 2.63 & 8.57 \\
\hline
\end{tabular}


(0.28 to 12.9) for Drins and $<0.26$ to $5.56(<0.26$ to 2.16 ) for PBDEs. PAHs, PCBs, DDTs, HCB, Mirex and PBDEs exhibited a similar distribution pattern, with the highest concentrations found in the central region of the coastline.

The highest concentrations of PAHs and their alkyl-substituted compounds were found in Santos, which is the most populated city on the coast of the state of São Paulo (Fig. 2). The variability in the concentrations of these compounds in stranded pellets along Santos Bay, where the samples in the present study were collected, was previously reported by Fisner et al. (2013a) and proved to be relatively high, ranging from 130 to $27,735 \mathrm{ng} \mathrm{g}^{-1}$ for PAHs and 198 to $1042 \mathrm{ng} \mathrm{g}^{-1}$ for alkylsubstituted compounds. PAH concentrations were relatively high along the northern beaches (Fig. 2), where submarine sewage outfalls and the largest Brazilian terminal (Almirante Barroso Maritime Terminal) for loading and unloading crude oil are found. The gross capacity of this terminal is about 1.6 million $\mathrm{m}^{3}$ of petroleum distributed among 20 oil tanks and another 17 tanks for oil derivatives, alcohol and biodiesel (Transpetro, 2013). Moreover, predominant currents from the south towards the north (Castro and Miranda, 1998) can also transport contaminants, including pellets, and contribute to such relatively high concentrations.

The relatively high amount of two-ring and three-ring PAHs (Fig. 2) at the majority of sites may be associated with oil or derivatives where such compounds are predominant (Yunker et al., 2002). The presence of vessels ranging from fishing boats (mainly on the southern coast) to large cargo and oil ships in the Baixada Santista as well as on the northern coast may contribute to the release of oil in seawater. Since low molecular PAHs are easily weathered in the environment, relatively more stable and heavier compounds (four to six rings) exhibit relatively higher amounts. The presence of the PAH HMW can also be attributed to the atmospheric deposition of compounds from the incomplete combustion of oil and derivatives (Yunker et al., 2002).

Hirai et al. (2011) found a similar PAH range (1 to $9300 \mathrm{ng} \mathrm{g}^{-1}$ ), with higher concentrations in plastic fragments collected close to sites under the influence of anthropogenic activities in comparison to samples collected from remote areas and the open sea. Rios et al. (2007) found PAHs in synthetic polymers collected in the North Pacific Gyre, California, Hawaii and Guadalupe Island (Mexico). Concentrations of priority PAHs ranged from 39 to $1200 \mathrm{ng} \mathrm{g}^{-1}$, with the highest amounts found in samples collected near industrial sites. Van et al. (2012) also analyzed plastic debris, including pre-production pellets and postconsumer plastics, collected from eight beaches around San Diego (California, USA) and found PAH concentrations between 18 and $1900 \mathrm{ng} \mathrm{g}^{-1}$. The lowest concentrations of PAHs in the present study were found on the southern beaches, where contaminant inputs are related to fishing boats and tourism and were comparable to the minimum concentrations found in pellets from selected Greek beaches ( $\Sigma_{9}$ PAHs -23 to $500 \mathrm{ng} \mathrm{g}^{-1}$ ) (Karapanagioti et al., 2011).

As occurred with PAHs, the highest concentrations of DDTs were found in Santos and relatively high amounts were found towards the northern region (Fig. 3). DDT concentrations in the pellets analyzed were relatively higher than those found in other parts of the world (Table 2), such as those reported by Mato et al. (2001) in pellets collected in Japan, those reported by Ogata et al. (2009), who analyzed samples from 17 countries in the initial phase of International Pellet Watch, and those reported by Zhang et al. (2015), who investigated DDT concentrations in pellets collected from two beaches in China, one of which was close to the largest coal port in the country. In contrast, Rios et al. (2007) found much higher concentrations of DDT ( $7100 \mathrm{ng} \mathrm{g}^{-1}$ ) in pellets than those reported in the present study. The authors attributed such high concentrations to the proximity to an industrial area in Los Angeles (USA) and the extensive use of this compound when it was still legal.

DDT concentrations along the coast of São Paulo were slightly lower than those found in South Africa, where this compound was still used in anti-malarial operations and even illegally in agricultural applications at the time of collection (i.e., 2005 and 2008) (Ryan et al., 2012). As in South Africa, DDT was heavily used in Brazilian agriculture to combat the vector that causes malaria, mainly in the northeastern region of the country (Lara and Batista, 1992). The production of DDT in Brazil was estimated to be 75,500 tons from 1959 to 1982 and its importation was estimated to 34,500 tons until 2003 (Almeida et al., 2007). DDT was officially banned in Brazil for all uses and storage on May 14, 2009, when Law 11.036 was issued (Brasil, 2009). However, DDT in its original form was still found in pellet samples at the time of collection, likely due to the existence of illegal applications or dumpsites as well as the presence of DDT as an impurity in other permitted pesticides, such as dicofol (D'Amato et al., 2002). In 2000, Brazil produced 209 tons of dicofol and imported a further 111 tons (UNEP, 2012).

The proportion of DDE, DDD and DDT varied among locations. At three sites (São Vicente, Santos and São Sebastião), a higher proportion of DDT was found in comparison to DDE and DDD. The degradation of DDT to DDD or DDE may occur in dumpsites, mainly in the Baixada Santista, before being carried to the marine environment. The transformation may occur also in sediment, from which the DDT metabolite may be re-suspended and desorbed in water, followed by further sorption to pellets.

Mean PCB concentrations in the pellets also revealed considerable variation along coast of São Paulo (Fig. 4). The lowest concentration (3.41 $\mathrm{ng} \mathrm{g}^{-1}$ ) was found in Enseada da Baleia in the municipality of Cananéia. Heskett et al. (2012) suggest that concentrations of PCBs below $10 \mathrm{ng} \mathrm{g}^{-1}$ are background levels. The samples from Guarujá

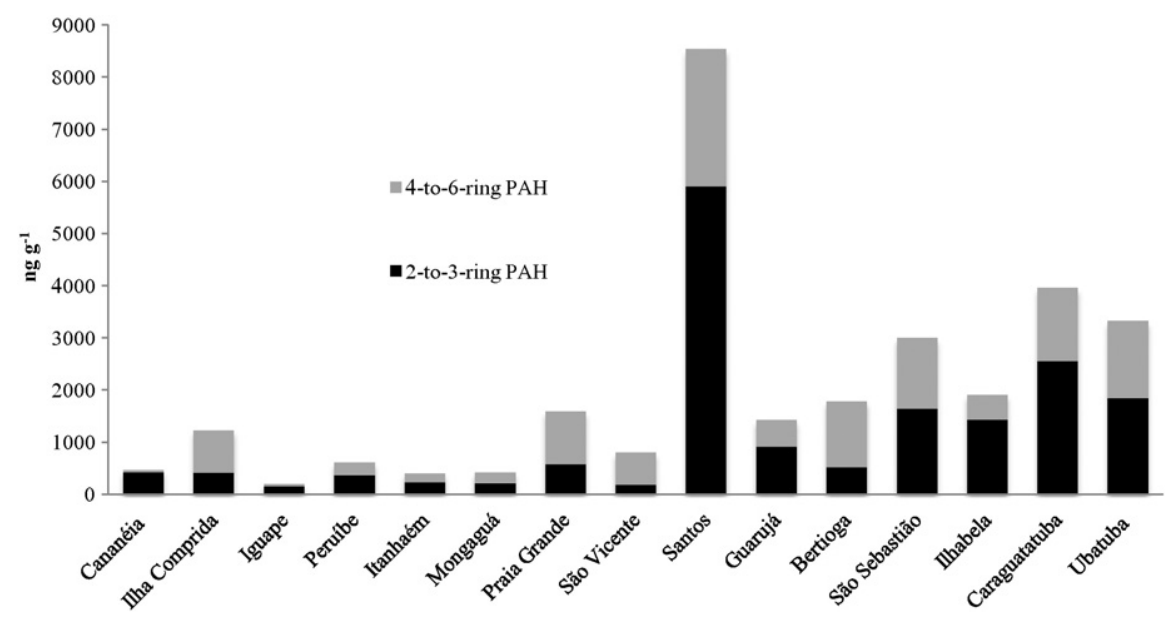

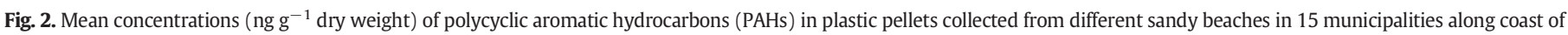
state of São Paulo, Brazil. 


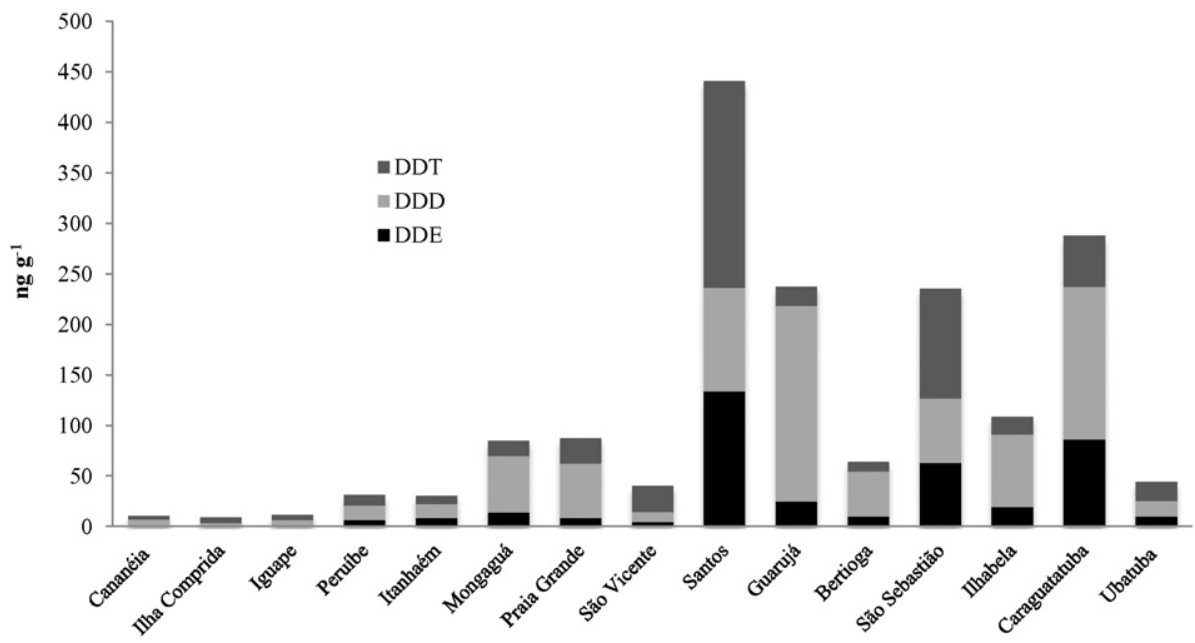

Fig. 3. Mean concentrations (ng g ${ }^{-1}$ dry weight) of dichlorodiphenyltrichloroethane (DDT) in plastic pellets collected along coast of state of São Paulo, Brazil.

and Santos, where many contaminants can be found at dumpsites (Lamparelli et al., 2001), had the highest concentrations of $\sum_{51} \mathrm{PCB}$ (3030 $\mathrm{ng} \mathrm{g}^{-1}$ and $1112 \mathrm{ng} \mathrm{g}^{-1}$, respectively). $\sum_{13} \mathrm{PCB}$, which is used for IPW (Ogata et al., 2009), was 2062 and $730 \mathrm{ng} \mathrm{g}^{-1}$ for Guarujá and Santos, respectively, and is classified as Category 5 of the five contamination categories $(1=$ lowest contamination; $5=$ highest contamination) (Takada and Yamashita, 2016), indicating that the state of São Paulo, especially around Guarujá and Santos, has a coast that is among the most highly contaminated with PCBs in the world.

The samples collected from the beaches of the Baixada Santista in 2012 also had very high concentrations in comparison to other places in the world (Table 2). $\sum_{13}$ PCB ranged from 1569 to $10,504 \mathrm{ng} \mathrm{g}^{-1}$ (Fig. 5). Pellets from the same site collected in 2009 and 2014 at Goes beach in the municipality of Guarujá had lower concentrations (369 and $406 \mathrm{ng} \mathrm{g}^{-1}$, respectively) than the $1640 \mathrm{ng} \mathrm{g}^{-1}$ found in 2012, likely due to occasional inputs of Askarel oil, which was a commercial PCB mixture used in Brazil that contained 40 to $60 \%$ chlorine. Owners of PCB oil and equipment containing or contaminated with PCB in the country are required to register their holdings with the pertinent environmental and regulatory agencies. However, it is recognized that the inventory may not portray all contaminated equipment (UNEP, 2012). More than 80,000 tons are estimated to be present in old, abandoned equipment, mainly related to deactivated power plants (Almeida et al., 2007), which can leak and release PCBs into the environment. Contaminated material from some landfills can be carried by rain, especially in summer, and deposited in the sea.

Sediment dredging could be also an important source of PCBs in the Baixada Santista, since the maintenance of port activities and safe navigation in the Port of Santos requires constant dredging of both fairways and berthing docks (Cesar et al., 2014). The authors cited found PCB concentrations between undetected and $182 \mu \mathrm{g} \mathrm{kg}^{-1}$ in sediment and the highest concentration was found where the dredged material was deposited. Bícego et al. (2006) found $240 \mathrm{ng} \mathrm{g}^{-1}$ in the most contaminated area of the Santos-São Vicente estuary complex. Waters from this estuary system flow out of Santos Bay (Harari and Camargo, 1998) and do not favor the accumulation of POPs in the sediment. Since pellets float on water surface, they can adsorb contaminants that are dispersed from the dredging region to other sites before reaching the beaches.

Table 2

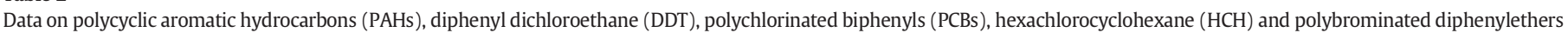
(PBDEs) in pre-production pellets or post-consumer plastic debris $\left(\mathrm{ng} \mathrm{g}^{-1}\right)$.

\begin{tabular}{|c|c|c|c|c|c|c|}
\hline Site & $\begin{array}{l}\text { ¿PAH (\# of } \\
\text { compounds) }\end{array}$ & $\Sigma$ DDT & $\begin{array}{l}\Sigma \mathrm{PCB} \text { (\# of } \\
\text { congeners) }\end{array}$ & $\Sigma \mathrm{HCH}$ & $\Sigma$ PBDE & Reference \\
\hline Japanese coast & - & $0.16-3.1(\mathrm{DDE})$ & $4-117$ & - & - & Mato et al. (2001) \\
\hline Tokyo, Japan & - & - & $<28-2300$ & - & - & Endo et al. (2005) \\
\hline $\begin{array}{l}\text { Pacific Gyre, California and Hawaii (USA) Guadalupe } \\
\text { Island (Mexico) }\end{array}$ & $39-1200(16)$ & $22-7100$ & $27-980(36)$ & - & - & Rios et al. (2007) \\
\hline 17 countries IPW initial phase & - & $1.69-267$ & $5-605(13)$ & $0.14-37.1$ & - & Ogata et al. (2009) \\
\hline Portuguese coast & $0.2-319.2(15)$ & $0.16-4.05$ & $0.02-15.56$ & - & - & Frias et al. (2010) \\
\hline Greece & $160-500(18)$ & $0.84-42$ & $5-290(19)$ & $1.05-3.5$ & - & Karapanagioti et al. (2011) \\
\hline Open sea, remote and urban beaches & $1-9300(14)$ & $0.2-198$ & $1-436(13)$ & - & $0.3-9909$ & Hirai et al. (2011) \\
\hline San Diego, California, USA & $18-210(16)$ & n.d. -75 & $3.8-42$ & - & - & Van et al. (2012) \\
\hline Remote islands in Pacific, Atlantic and Indian Ocean & - & $0.8-4.1$ & $1.1-9.9(13)$ & $0.6-1.7$ & - & Heskett et al. (2012) \\
\hline South Africa coast & - & $8.0-1281$ & $16-113(13)$ & $2-112$ & - & Ryan et al. (2012) \\
\hline Santos Bay, Brazil & $\begin{array}{l}130-27,735(35) \\
86.6-6815(16)\end{array}$ & - & - & - & - & Fisner et al. (2013a) \\
\hline Santos Bay, Brazil & $\begin{array}{l}386-1996(35) \\
198-1042(16)\end{array}$ & - & - & - & - & Fisner et al. (2013b) \\
\hline Portuguese coast & $53-44,800(17)$ & $0.42-41$ & $2-223(18)$ & & - & Antunes et al. (2013) \\
\hline Portuguese coast & $50-400(33)$ & $<$ LOQ-49 & $10-310$ & $<1-3.3$ & - & Mizukawa et al. (2013) \\
\hline China & $136.3-2384.2(16)$ & $1.2-127.0$ & $21.5-323.2(20)$ & n.d. -1.90 & - & Zhang et al. (2015) \\
\hline Belgian coast & 1076-3007 (16) & - & $31-236(7)$ & - & - & Gauquie et al. (2015) \\
\hline São Paulo coast, Brazil & $\begin{array}{l}192-13,708(35) \\
32.6-2068(16)\end{array}$ & $<0.11-840$ & $\begin{array}{l}3.41-7554(51) \\
<0.51-5604(13)\end{array}$ & $<0.24-4.10$ & $<0.76-5.56$ & This study \\
\hline
\end{tabular}

n.d. - not detected or below method detection limit.

LOQ - limit of quantification. 


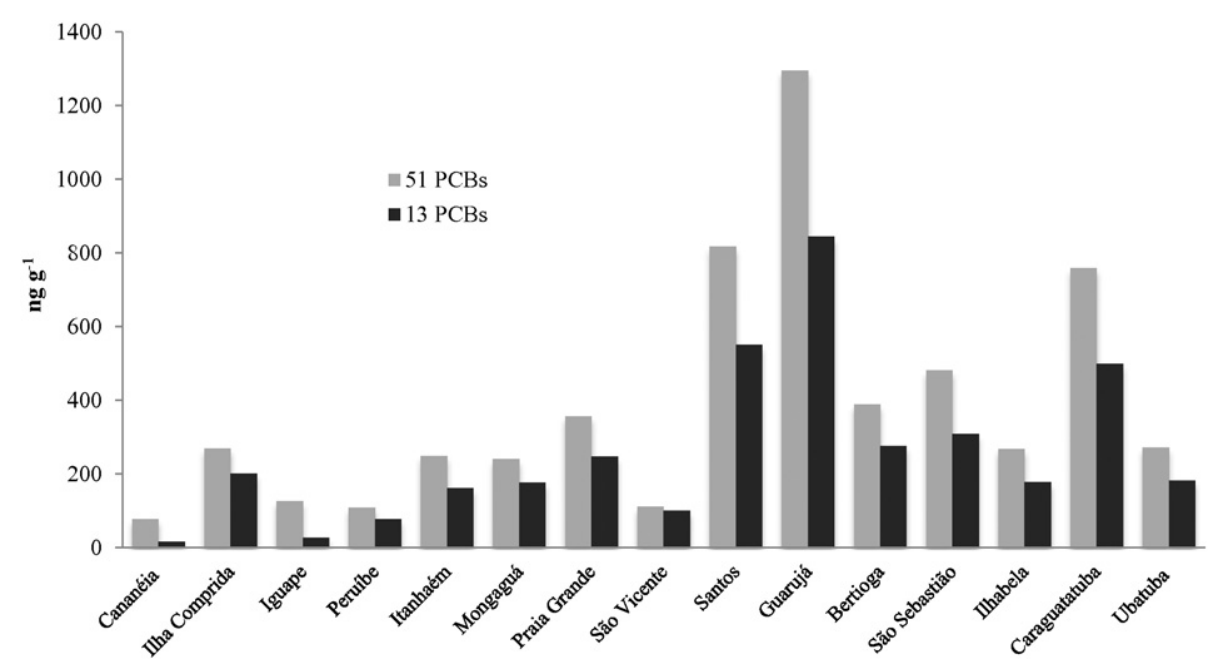

Fig. 4. Mean concentrations (ng g ${ }^{-1}$ dry weight) of polychlorinated biphenyls (PCBs) in beach-stranded plastic pellets collected along coast of São Paulo, Brazil.

The majority of plastic pellet samples analyzed in the present study exhibited the predominance of hexachlorobiphenyls, followed by heptachlorobiphenyls and pentachlorobiphenyls, which is similar to the distribution reported for pellets from industrialized areas (Mizukawa et al., 2013). The highest mean concentrations in the present study were found for congeners 138, 153 and 180, as also described by Frias et al. (2010) on the Portuguese coast and Karapanagioti et al. (2011) for pellets collected from Greek beaches. This predominance is usually found in urban areas, such as the coast of São Paulo. The predominance of light congeners mainly tetrachlorobiphenyls, such as PCB-49 and 52, was only detected at four of the 41 sites, such as in the municipality of Cananéia, which is not close to any PCB source. This profile is usually associated with more pristine areas, such as remote islands (Heskett et al., 2012). The samples collected in 2012 had higher amounts of lighter congeners than heavier congeners, with ratio of the sum of CB-187, 180, 170, 206 to the sum of CB-66, 101, 110, 118, 105 [7,9-CBs/4,5-CBs ratio, such as defined and applied in Hosoda et al. (2014)] around 0.4. These ratios were much lower than those for the pellet samples collected in 2009/10 (1.3 and 2.2) and 2014 (0.8). The predominance of lighter congeners suggests episodic and recent inputs of PCBs.

Hexachlorobenzene and mirex demonstrated similar distribution along the coast, with higher concentrations at beaches in Santos. HCB may be released into the environment as a product of incomplete waste combustion in incinerators and a by-product of industrial processes (Lohse, 1988; Tanabe et al., 1997). Moreover, this product has also been used as a fungicide in some countries (Ecobichon, 1996). Among other chlorinated pesticides, HCB was dumped at several sites in the Baixada Santista (do Nascimento et al., 2004) and caused considerable environmental and health problems, such as leukopenia (Santos Filho et al., 2005).

In Brazil, Uruguay and Argentina, mirex is popularly known as dodecachlor and was principally used for ant control, with restricted distribution in the region (UNEP, 2002). According to the UNEP (2012), mirex was not produced in Brazil, but about 191 tons were imported in 1989. Mirex was forbidden in 1992 through regulations issued by the Ministry of Agriculture (MAPA 63/92). This pollutant was used as both a pesticide and flame retardant in the state of São Paulo (Yogui et al., 2010) and its persistence is associated with the high chlorination level.

Hexachlorocyclohexane $(\mathrm{HCH})$ did not exhibit considerable differences among the samples collected along the coast of São Paulo besides a small increase towards the Baixada Santista and northern beaches. The low concentrations reflect the less retention of $\mathrm{HCH}$ due to relatively lower hydrophobicity and higher vapor pressure in comparison to PCBs (Ogata et al., 2009). The concentrations of $\mathrm{HCH}$ found in several

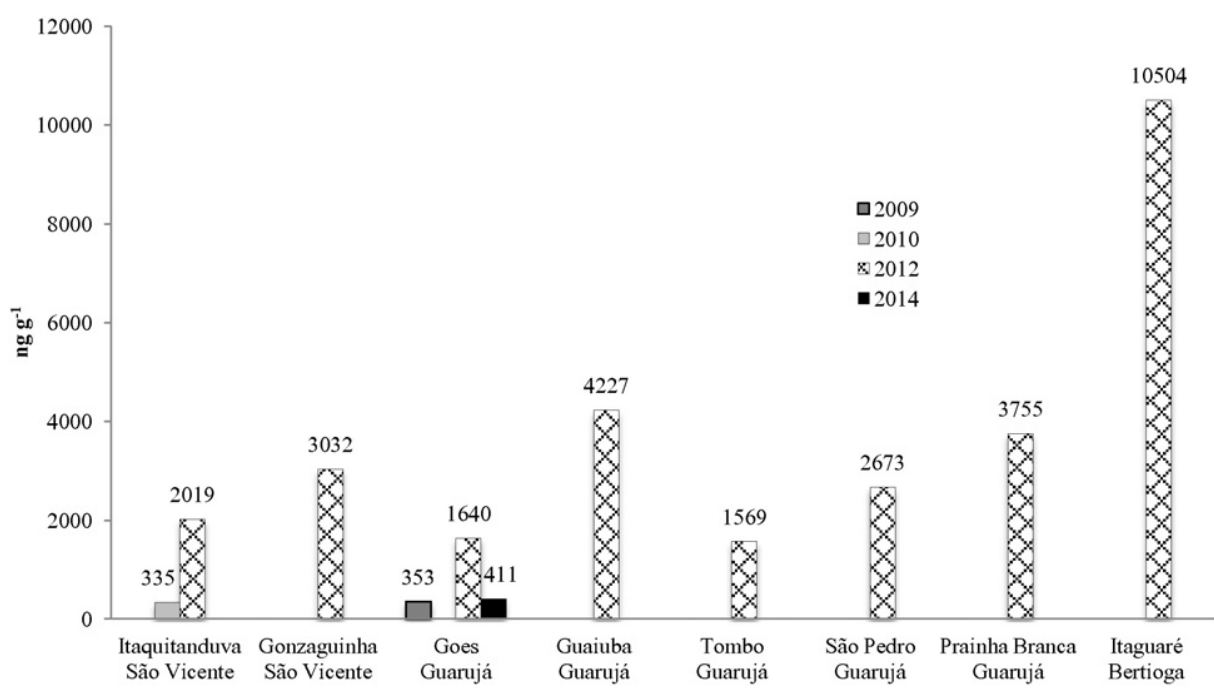

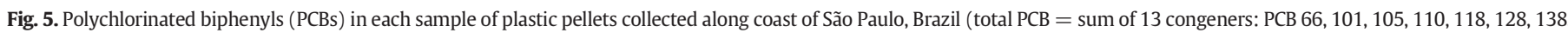
$149,153,170,180,187$ and 206). 
countries by the authors cited during the initial phase of International Pellet Watch program ranged from 0.14 to $37.1 \mathrm{ng} \mathrm{g}^{-1}$, demonstrating that these compounds were used at that time in some places, such as Mozambique. HCHs were widely employed in Brazil in cotton and coffee plantations (Lara and Batista, 1992) until 1985, when these chemicals were banned for agricultural use (Directives MAPA 326/1985) (Almeida et al., 2007). HCHs were used in public health campaigns against insects (Triatoma sp.) that cause Chagas' disease. Isomers of $\mathrm{HCH}$ and particularly $\gamma$-HCH were heavily used (Anvisa, 2007) until the ban on January 8th, 1998 (Directive 11/1998) (Almeida et al., 2007). In 2007, however, the use of Lindane was still permitted as a wood preservative in Brazil (Anvisa, 2007).

HCH production was estimated to be 18,400 tons from 1955 to 1982 and its importation was estimated to 7000 tons until 2003 (Almeida et al., 2007). According to the Brazilian Ministry of Industry and Commercial Development (http://aliceweb.desenvolvimento.gov.br/), an import record of 14 tons until 2003 was only reported after 1996. Brazil imported 900 tons of Lindane in a span of over twenty years between 1961 and 1982 and 600 tons in a span of only seven years between 1996 and 2003. HCHs are much less bioaccumulative than other organochlorines due to their relatively low degree of liphophilicity. In contrast, the relatively high vapor pressures, particularly for the $\alpha-\mathrm{HCH}$ isomer, determine the long-range transport of these pollutants in the atmosphere (UNEP, 2002).

Among the 41 samples analyzed, only 10 had PBDE concentrations above the MDL, albeit at very low levels. PBDEs are added to a variety of products, such as plastics, textiles and furniture foam, due to their flame retardant capacity (Rahman et al., 2001). These pollutants are slowly and continuously released into the environment through a number of different pathways (e.g. Chen and Hale, 2010; Hale et al., 2003). Only PBDE-47 was detected in all samples. In the sample from Itaóca in the municipality of Mongaguá, BDE 99 and 100 were also found. Moreover, only BDE-100 was above the MDL at Gonzaga Beach in the city of Santos.

There are no records of production of PBDE in Brazil, but the presence in the samples demonstrates that these chemicals are available in the environment. PBDE flame retardant formulas available in the Americas (e.g., technical Bromkal 70-5DE) contain approximately $37 \%$, $35 \%$ and $6.8 \%$ of the congeners 47, 99 and 100, respectively (Sjödin et al., 1998). However, it was difficult to evaluate the distribution of PBDE congeners in the pellet samples due to the low concentrations. Hirai et al. (2011) found PBDE (20 congeners) concentrations ranging from 0.3 to $9909 \mathrm{ng} \mathrm{g}^{-1}$, with the highest concentrations attributed to BDE-209, which was not analyzed in the present investigation.

\section{Conclusion}

The PAHs, PCBs, OCPs and PBDEs found in plastic pellets collected from the beaches of each city along the coast of the state of São Paulo (Brazil) reflect the influence of industrial and urban inputs as well as products used in agriculture and against vectors that cause diseases, such as malaria. Currents also seem to play an important role in the transportation of contaminants, whether adsorbed to pellets or not, towards the north, where fewer pollution sources are found and the environment is not as heavily contaminated as Baixada Santista. The temporal variation in pellet contamination reflects a dynamic and complex process as well as episodic inputs of products containing PCBs. The plastic pellets demonstrated the contribution of local sources of contaminants as well as compounds accumulated during the transport of pellets through different types of environments before reaching the beaches.

\section{Acknowledgments}

The authors are thankful to the São Paulo State Funding Agency (FAPESP 2007/51924-7; 2015/17881-5) for the financial support and to the National Council for Scientific and Technological Development (CNPq) for the productivity grant to R.C. Montone (307898/2014-8), M.C. Bícego (307219/2014-3) and A. Turra (301240/2006-0).

\section{References}

Abessa, D.M.S., Carr, R.S., Rachid, B.R.F., Sousa, E.C.P.M., Hortelani, M.A., Sarkis, J.E., 2005. Influence of a Brazilian sewage outfall on the toxicity and contamination of adjacent sediments. Mar. Pollut. Bull. 50, 875-885.

Almeida, F.V., Centeno, A.J., Bisinoti, M.C., Jardim, W.F., 2007. Substâncias tóxicas persistentes (STP) no Brasil. Quim. Nova 30, 1976-1985.

Antunes, J.C., Frias, J.G.L., Micaelo, A.C., Sobral, P., 2013. Resin pellets from beaches of the Portuguese coast and adsorbed persistent organic pollutants. Estuar. Coast. Shelf Sci. $130,62-69$.

Anvisa, 2007. Nota técnica sobre a reavaliação toxicológica do ingrediente ativo Lindano. http://www.portal.anvisa.gov.br/wps/wcm/connect/ c99bf100474595769d6bdd3fbc4c6735/lindano.pdf?MOD=AJPERES (accessed October, 2015).

Baumard, P., Budzinski, H., Garrigues, P., Dizer, H., Hansen, P.D., 1999. Polycyclic aromatic hydrocarbons in recent sediments and mussels (Mytilus edulis) from the Western Baltic Sea: occurrence, bioavailability and seasonal variations. Mar. Environ. Res. 47, $17-47$.

Bícego, M.C., Taniguchi, S., Yogui, G.T., Montone, R.C., Silva, D.A.M., Lourenço, R.A., Martins, C.C., Sasaki, S.T., Pellizari, V.H., Weber, R.R., 2006. Assessment of contamination by polychlorinated biphenyls and aliphatic and aromatic hydrocarbons in sediments of the Santos and São Vicente Estuary System, São Paulo, Brazil. Mar. Pollut. Bull. 52, $1784-1832$.

Brasil, 2009. Lei No. 11.936 - Proíbe a fabricação, a importação, a exportação, a manutenção em estoque, a comercialização e o uso de diclorodifeniltricloretano (DDT) e dá outras providências. http://www.planalto.gov.br/ccivil_03/_Ato2007010/2009/Lei/L11936.htm.

Brasil, 2015. Instituto Brasileiro de Geografia e Estatística - IBGE. http://www.cidades. ibge.gov.br/ (accessed October, 2015).

Castro, B.M., Miranda, L.B., 1998. Physical oceanography of the western Atlantic continental shelf located between $4^{\circ} \mathrm{N}$ and $34^{\circ} \mathrm{S}$. In: Robinson, A.R., Brink, K.H. (Eds.), The Sea Vol. 11. John Wiley \& Sons, New York, pp. 209-252.

Cesar, A., Lia, L.R.B., Pereira, C.D.S., Santos, A.R., Cortez, F.S., Choueri, R.B., De Orte, M.R., Rachid, B.R.F., 2014. Environmental assessment of dredged sediment in the major Latin American seaport (Santos, São Paulo - Brazil): an integrated approach. Sci. Total Environ. 497-498, 679-687.

Chen, D., Hale, R.C., 2010. A global review of polybrominated diphenyl ether flame retardant contamination in birds. Environ. Int. 36, 800-811.

Colabuono, F.I., Taniguchi, S., Montone, R.C., 2010. Polychlorinated biphenyls and organochlorine pesticides in plastics ingested by seabirds. Mar. Pollut. Bull. 60, 630-634.

D'amato, C., Torres, J.P.M., Malm, O., 2002. DDT (dicloro difenil tricloroetano): toxicidade e contaminação ambiental - uma revisão. Quim. Nova 25, 995-1002.

do Nascimento, N.R., Nicola, S.M.C., Rezende, M.O.O., Oliveira, T.A., Oberg, G., 2004. Pollution by hexachlorobenzene and pentachlorophenol in the coastal plain of São Paulo state, Brazil. Geoderma 121, 221-232.

Ecobichon, C.D., 1996. Toxic effects of pesticides. In: Klaassen, C.D. (Ed.), Casarett and Doull's Toxicology: The Basic Science of Poisons, fifth ed. McGraw-Hill, New York, pp. 643-689.

Endo, S., Takizawa, R., Okuda, K., Takada, H., Chiba, K., Kanehiro, H., Ogi, H., Yamashita, R., Date, T., 2005. Concentration of polychlorinated biphenyls (PCB) in beached resin pellets: variability among individual particles and regional differences. Mar. Pollut. Bull. 50, 1103-1114.

Fisner, M., Taniguchi, S., Majer, A.P., Bícego, M.C., Turra, A., 2013a. Concentration and composition of polycyclic aromatic hydrocarbons $(\mathrm{PAH})$ in plastic pellets: implications for small-scale diagnostic and environmental monitoring. Mar. Pollut. Bull. 76, 349-354.

Fisner, M., Taniguchi, S., Moreira, F., Bícego, M.C., Turra, A., 2013b. Polycyclic aromatic hydrocarbons (PAH) in plastic pellets: variability in the concentration and composition at different sediment depths in a sandy beach. Mar. Pollut. Bull. 70, 219-226.

Frias, J.P.G.L., Sobral, P., Ferreira, A.M., 2010. Organic pollutants in microplastics from two beaches of the Portuguese coast. Mar. Pollut. Bull. 60, 1988-1992.

Gauquie, J., Devriese, L., Robbens, J., De Witte, B., 2015. A qualitative screening and quantitative measurement of organic contaminants on different types of marine plastic debris. Chemosphere 138, 348-356.

Gutberlet, J., 1997. Cubatão: desenvolvimento, exclusão social degradação ambiental. EDUSP, São Paulo, p. 244.

Hale, R.C., Alaee, M., Manchester-Neesvig, J.B., Heather, M., Stapleton, H.M., Ikonomou, M.G., 2003. Polybrominated diphenyl ether flame retardants in the North American environment. Environ. Int. 29, 771-779.

Harari, J., Camargo, R., 1998. Modelagem numérica da região costeira de Santos (SP): Circulação de maré. Rev. bras. Oceanogr. 46, 135-156.

Heskett, M., Takada, H., Yamashita, R., Yuyama, M., Ito, M., Geok, Y.B., Ogata, Y., Kwan, C., Heckhausen, A., Taylor, H., Powell, T., Morishige, C., Young, D., Patterson, H., Robertson, B., Bailey, E., Mermoz, J., 2012. Measurement of persistent organic pollutants (POPs) in plastic resin pellets from remote islands: toward establishment of background concentrations for International Pellet Watch. Mar. Pollut. Bull. 64, 445-448.

Hirai, H., Takada, H., Ogata, Y., Yamashita, R., Mizukawa, K., Saha, M., Kwan, C., Moore, C., Gray, H., Laursen, D., Zettler, E.R., Farrington, J.W., Reddy, C.M., Peacock, E.E., Ward, M.W., 2011. Organic micropollutants in marine plastics debris from the open ocean and remote and urban beaches. Mar. Pollut. Bull. 62, 1683-1692. 
Hosoda, J., Ofosu-Anim, J., Sabi, E.B., Akita, L.G., Onwona-Agyeman, S., Yamashita, R. Takada, H., 2014. Monitoring of organic micropollutants in Ghana by combination of pellet watch with sediment analysis: E-waste as a source of PCB. Mar. Pollut. Bull. 86, 575-581.

Jones, K.C., de Voogt, P., 1999. Persistent organic pollutants (POPs): states of the science. Environ. Pollut. 100, 209-221.

Karapanagioti, H.K., Endo, S., Ogata, Y., Takada, H., 2011. Diffuse pollution by persistent organic pollutants as measured in plastic pellets sampled from various beaches in Greece. Mar. Pollut. Bull. 62, 312-317.

Lamparelli, M.C., Costa, M.P., Prósperi, V.A., Bevilacqua, J.E., Arauújo, R.P.A., Eysink, G.G.J., Pompéia, S., 2001. Sistema estuarino de Santos e São Vicente Relatório Técnico CETESB. São Paulo. p. 183.

Lara, W.H., Batista, G.C., 1992. Pesticidas. Quim. Nova 15, 161-166.

Lohse, J., 1988. Ocean incineration of toxic wastes: a footprint in North Sea sediments. Mar. Pollut. Bull. 19, 366-371.

Mato, Y., Isobe, T., Takada, H., Kanehiro, H., Ohtake, C., Kaminuma, T., 2001. Plastic resin pellets as a transport medium toxic chemicals in the marine environment. Environ. Sci. Technol. 35, 318-324.

MDIC (Ministério do Desenvolvimento da Indústria e Comércio), 2015o. http://aliceweb. mdic.gov.br (accessed in October, 2015).

Mizukawa, K., Takada, H., Ito, M., Geok, Y.B., Hosoda, J., Yamashita, R., Saha, M., Suzuki, S., Miguez, C., Frias, J., Antunes, J.C., Sobral, P., Santos, I., Micaelo, C., Ferreira, A.M., 2013. Monitoring of a wide range of organic micropollutants on the Portuguese coast using plastic resin pellets. Mar. Pollut. Bull. 70, 296-302.

Ogata, Y., Takada, H., Mizukawa, K., Hirai, H., Iwasa, S., Endo, S., Mato, Y., Saha, M., Okuda, K., Nakashima, A., Murakami, M., Zurcher, N., Booyatumanondo, R., Zakaria, M.P. Dung, L.Q., Gordon, M., Miguez, C., Suzuki, S., Moore, C., Karapanagioti, H.K., Weerts, S., McClurg, T., Burres, E., Smith, W., Velkenburg, M.V., Lang, J.S., Lang, R.C., Laursen, D., Danner, B., Stewardson, N., Thompson, R.C., 2009. International pellet watch: global monitoring of persistent organic pollutants (POPs) in coastal waters. 1. Initial phase data on PCB, DDT, and HCHs. Mar. Pollut. Bull. 58, 1437-1446.

Rahman, F., Langford, K.H., Scrimshaw, M.D., Lester, J.N., 2001. Polybrominated diphenyl ether (PBDE) flame retardants. Sci. Total Environ. 275, 1-17.

Rios, L.M., Moore, C., Jones, P.R., 2007. Persistent organic pollutants carried by synthetic polymers in the ocean environment. Mar. Pollut. Bull. 54, 1230-1237.

Ryan, P.G., Bouwman, H., Moloney, C.L., Yuyama, M., Takada, H., 2012. Long-term decreases in persistent organic pollutants in South African coastal waters detected from beached polyethylene pellets. Mar. Pollut. Bull. 62, 2756-2760.

Santos Filho, E., Silva, R.S., Lemes, V.R.R., Barretto, H.H.C., Inomata, O.N.K., K., Tereza A., Rocha, S.O.B., 2005. Alterações clínicas e laboratoriais relacionadas à exposição ambiental aos praguicidas organoclorados em moradores de aterro à céu aberto Cubatão, S.P. Clinical and laboratorial adverse effects from exposition to organochlorine pesticides in inhabitants of dump site in Cubatão, S.P. Rev. Inst. Adolfo Lutz 64 70-78.

Sjödin, A., Jakobsson, E., Kierkegaard, A., Marsh, G., Sellström, U., 1998. Gas chromatographic identification and quantification of polybrominated diphenyl ethers in a commercial product, Bromkal 70-5DE. J. Chromatogr. A 822, 83-89.

Takada, H., Yamashita, R., 2016. Pollution status of persistent organic pollutants in Large Marine Ecosystems: Status and Trends. IOC-UNESCO, Paris, and UNEP, Nairobi $169-182$.

Tanabe, S., Madhusree, B., Öztürk, A.A., Tatsukawa, R., Miyazaki, N., Özdamar, E., Aral, O Samsun, O., Öztürk, B., 1997. Persistent organochlorine residues in harbour porpoise (Phocoena phocoena) from the Black Sea. Mar. Pollut. Bull. 34, 338-347.

Transpetro (Petrobrás Transporte S.A.), 2013. Área de negócios - terminais aquaviários. http://www.transpetro.com.br/pt_br/areas-de-negocios/terminais-e-oleodutos/ terminais-aquaviarios.html (Accessed November, 2015).

United Nations Environment Programme (UNEP), 2002. Eastern and western South America regional report, regionally based assessment of persistant toxic substances (Geneva, Switzerland).

United Nations Environmental Programme (UNEP), 2012. Supporting the global monitoring plan on persistent organic pollutants (Brazil).

Van, A., Rochman, C.M., Flores, E.M., Hill, K.L., Vargas, E., Vargas, S.A., Hoh, E., 2012. Persistent organic pollutants in plastic marine debris found on beaches in San Diego, California. Chemosphere 86, 258-263.

Wade, T.L., Cantillo, A.Y., 1994. Use of standards and reference materials in the measurement of chlorinated hydrocarbon residues. Chemistry WorkbookNOAA Technical Memorandum NOS ORCA 77. US Department of Commerce, Silver Spring, p. 59.

Yogui, G.T., Santos, M.C.O., Bertozzi, C.P., Montone, R.C., 2010. Levels of persistent organic pollutants and residual pattern of DDT in small cetaceans from the coast of São Paulo, Brazil. Mar. Pollut. Bull. 60, 1862-1867.

Yunker, M.B., Macdonald, R.W., Vingarzan, R., Mitchell, R.H., Goyette, D., Sylvestre, S., 2002. PAHs in Fraser River basin: a critical appraisal of PAH ratios as indicators of PAH source and composition. Org. Geochem. 33, 489-515.

Zhang, W., Ma, X., Zhang, Z., Wang, Y., Wang, J., Wang, J., Ma, D., 2015. Persistent organic pollutants carried on plastic resin pellets from two beaches in China. Mar. Pollut. Bull. 99, 28-34. 